\title{
Drying kinetics and quality aspects during heat pump drying of onion (Allium cepa L.)
}

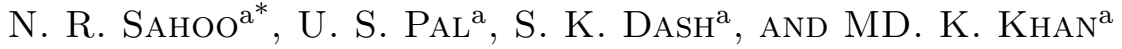 \\ a Department of Agricultural Processing and Food Engineering, Orissa University of Agriculture and Technology, \\ Bhubaneswar - 75100 \\ ${ }^{*}$ Corresponding author \\ niharouat@gmail.com \\ TEL: +91-674-2564774 \\ FAX: $+91-9437554348$
}

Received: 16 February 2012; Published online: 18 October 2012

\begin{abstract}
A prototype heat pump dryer has been developed for drying of fruits and vegetables at low temperature and relative humidity to maintain the quality of dried product. Onions, of Nasik red variety were peeled, trimmed and sliced to $2 \mathrm{~mm}$ thickness. The onion slices were dried in the heat pump dryer at $35^{\circ} \mathrm{C}(32 \%$ R.H. $), 40^{\circ} \mathrm{C}(26 \%$ R.H.), $45^{\circ} \mathrm{C}\left(19 \%\right.$ R.H.) and $50^{\circ} \mathrm{C}$ (15\% R.H.). Samples were also dried in a hot air dryer at $50^{\circ} \mathrm{C}(52 \%$ R.H.) for comparison. The drying rate increased with increase in drying air temperature, associated with reduced R.H., in the heat pump dryer. Drying took place mainly under the falling rate period. The Page equation, resulting in a higher coefficient of determination and lower root mean square error, better described the thin-layer drying of onion slices than the Henderson and Pabis equation. Heat pump drying took less drying time of 360 min and yielded better quality dried product, with higher retention of ascorbic acid and pyruvic acid and lower colour change, as compared to a hot air dryer at the same drying air temperature of $50^{\circ} \mathrm{C}$.
\end{abstract}

Keywords: Heat pump dryer, onion slices, Page equation, Henderson and Pabis equation

\section{Nomenclature}

$\theta \quad$ Drying time, min

A, n Empirical coefficients

d.b. Dry basis

d.m. Dry matter

DR Dehydration ratio

HAD Hot air drying/dryer

HDPE High density polyethylene

HPD Heat pump drying/dryer

$\mathrm{K} \quad$ Drying constant $\mathrm{min}^{-1}$

M Moisture content at time $\theta \quad \%$ (d.b.)

MR Moisture ratio

$\mathrm{M}_{e q} \quad$ Equilibrium moisture content \% (d.b.)

$\mathrm{M}_{\theta i} \quad$ Initial moisture content $\quad \%$ (d.b.)

RMSE Root mean square error

RR Rehydration ratio

$\Delta \mathrm{E} \quad$ Change in colour 


\section{Introduction}

Drying is an energy intensive process. The main objective of any drying process is to produce a dried product of desired quality at minimum cost and maximum throughput. Thermal drying is often conducted at high temperatures. However many agricultural and food materials (mainly crops) are sensitive to high temperatures. Dehydrated products usually suffer distinct losses in quality during processing. It is reported that the pigment, vitamin and essential oil degradation rates increase as the drying temperature increases (Malchev, Ioncheva, Tanchev, \& Kalpakchieva, 1982). Further conventionally air dried products do not rehydrate satisfactorily because of structural changes in the product due to excessive thermal damage (Holdsworth, 1986). Thus drying at low temperature to enhance the quality of food products has been a growing interest in recent years. A drying system that is both energy efficient and preserves product quality is desired (Adapa, Sokhansanj, \& Schoenau, 2002).

Heat pumps have been known to be energy efficient when used in conjunction with drying operations. The principal advantages of heat pump dryers emerge from the ability of heat pumps to recover energy from the exhaust air as well as their ability to control independently the drying air temperature and humidity. In most of the research studies conducted, the common conclusion was that heat pump drying (HPD) offers products of better quality with reduced energy consumption (Chua, Chou, Ho, \& Hawlader, 2002). Many researchers have acknowledged the importance of heat pump dryers in producing a range of precise conditions to dry a wide range of products and improve their quality. Heat sensitive food products, requiring low-temperature drying, can take advantage of the heat pump drying technology (Pal \& Khan, 2007). Recently, there has been a significant growth in the potential market for heat pump dryers, aided by the impact of new designs under development or recently introduced into the market

Onion (Allium cepa L.) is one of the most popular vegetables in the world. It is a vegetable widely consumed due to its flavour and health-promoting properties. It has been widely used, even in ancient times, as a seasoning, food and for medicinal purposes (Sharma, Verma, \& Pathare, 2005). It is a major vegetable in the Indian diet. The onion finds widespread usage in both fresh and dried forms. Dehydrated onion has gained importance on the world market due to its stability and smaller space requirements during storage, and lower transportation costs. Dried onions are made in several forms: flaked, minced, chopped and powdered. Good quality dehydrated onion should be high in pungency, because it is primarily used as a flavouring agent.

Hot air drying is simple and most widely used. However, major problems associated with hot air drying of onion are considerable shrinkage caused by cell collapse following the loss of water, the poor rehydration characteristics of the dehydrated product and undesirable changes in color, texture, flavour and nutritive value. The fundamental objective to create a shelf-stable product, in food drying is to minimally affect the desired quality attributes. The colour and flavour of the dried onion are considered as the most important quality attributes affecting the degree of acceptability of the product by the consumer (Kaymak-Ertekin \& Gedik, 2005). Conventional drying of onion inevitably results in loss of pungency because of the combined effects of time and temperature on the onion components (Pezzutti \& Crapiste, 1997). Most of the volatile flavour components have a low boiling point and ascorbic acid is temperature dependent which causes loss during drying at higher temperature (Adam, Mühlbauer, Esper, Wolf, \& Spiess, 2000). Thus it was considered that heat pump drying could be used for onions to maintain the product quality. The present study was undertaken to investigate the drying behaviour of onion slices in a heat pump dryer at lower temperature and relative humidity to obtain a quality product. The effect of drying air temperature on drying characteristics and quality of dried onion were analysed and compared with that of hot air drying.

\section{Materials and methods}

A prototype heat pump assisted dehumidified air tray dryer as shown in Fig.1 was used to dry onion slices. The developed dryer consists of a heat pump unit (evaporator, compressor, condenser, and expansion device) and drying chamber with trays. The dryer is a closed insulated chamber consisting of the dehumidifier unit, with evaporator and internal condenser at its upper portion, and drying chamber at its lower portion. The compressor and external condenser are located at the bottom of the chamber. The dryer is operated with a R22 (Freon 22) refrigerant. The tray dryer is fitted with a $1 \mathrm{~kW}$ compressor to operate the heat pump and an electrical fin (extended surface) heater in the air path for additional heating. A digital temperature controller 
was connected to the dryer for provision of variable drying air temperature (Pal \& Khan, 2008).

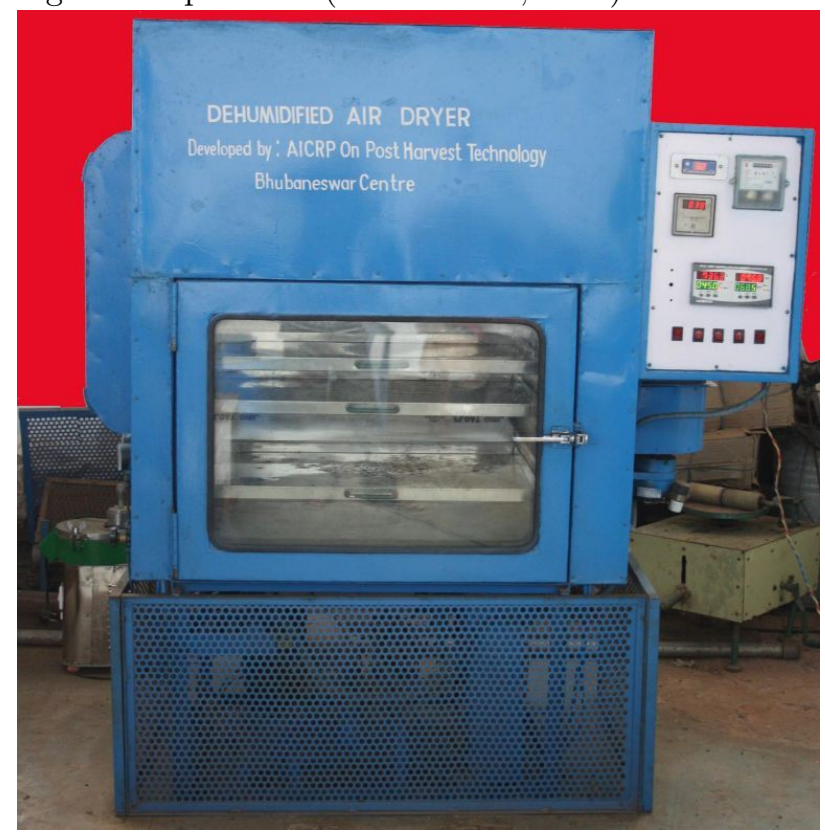

Figure 1: Heat pump assisted dehumidified air dryer

\subsection{Operation of the dryer}

The inlet drying air passes through the drying chamber and picks up moisture from the product. The moistureladen air is then directed to the evaporator coil. During the dehumidification process the air is first cooled sensibly to its dew point. Further cooling results in water being condensed from the air. Latent heat of vapourisation is then absorbed by the evaporator to boil the refrigerant. The recovered heat is "pumped" to the condenser. The cooled and dehumidified air then absorbs the heat at the internal condenser, for sensible heating to the desired temperature, and then passes to the dryer for drying the product. The dryer is energy efficient due to heat recovery from exhaust air and preserves product quality due to low temperature drying.

\section{$2.2 \quad$ Drying experiment}

Thin-layer drying experiments under controlled conditions were conducted for onion slices in a heat pump dryer (HPD). Onion, of Nasik red variety purchased from the local Indian market was used for the experiments. For each experiment, a group of similar size onions (bulb diameter $50 \pm 5 \mathrm{~mm}$ ) were chosen without visible damage. The onion samples selected were cleaned, hand peeled and trimmed. The onion was sliced to $2 \mathrm{~mm}$ thickness with a slicer and the slices were shredded to single pieces of length 15 to $20 \mathrm{~mm}$. During slicing of onions, care was taken to avoid any loss of juice or moisture. The sliced samples were placed in sealed polyethylene (HDPE) bags until drying.

About $500 \mathrm{~g}$ of onion slices were spread uniformly at a loading of $4.2 \mathrm{~kg} / \mathrm{m}^{2}$ in a thin layer on the drying trays. The experiments were conducted at $35^{\circ} \mathrm{C}(32$ $\%$ R.H.), $40^{\circ} \mathrm{C}$ (26 \% R.H.), $45^{\circ} \mathrm{C}$ (19\% R.H.) and $50^{\circ} \mathrm{C}$ (15\% R.H.) drying air conditions in the heat pump dryer. Samples were also dried in a hot air dryer (HAD) at $50^{\circ} \mathrm{C}(52 \%$ R.H.) for comparison. The dryer was turned on 1 hour before the experiment to achieve the desired steady drying air temperature. All experiments were carried out at a constant air velocity of $1 \mathrm{~m} / \mathrm{s}$. The weight of the samples was taken at regular intervals of 30 minutes until constant weight was attained by the samples, which was the indication of attaining equilibrium with the exposed environment. The initial and final moisture content of the samples were determined gravimetrically by the hot air oven method (Williams, 1984). Drying rate was calculated from the experimental data (Eq.1) and drying characteristics curves were plotted. Dehydrated shreds were packed quickly in polyethylene bags and stored in desiccators for further analysis. The dehydration ratio (DR) was determined by taking the ratio of weight of sample before and after drying. The drying rate for each time interval at each drying temperature was calculated by considering the water removed per unit time for the particular interval.

$$
\text { Drying Rate }=\frac{\text { Amount of water removed }}{\text { Time taken } \times \text { Amount of bonedry material }} \times 100
$$




\subsection{Theoretical considerations}

Modern methods for designing air drying operations require the mathematical description of food moisture movement during the process, known as drying kinetics (Hernandez, Pavon, \& Garcia, 2000). Among the wide range of mathematical models, thin layer drying models have found wide application due to their ease of use (Madamba, Driscoll, \& Buckle, 1996) and as they contribute to the understanding of the drying characteristics of agricultural materials. Many researchers have proposed numerous mathematical models for thin-layer drying of agricultural products. Henderson and Pabis (1961) introduced an equation analogous to Newton's law of cooling, of the form:

$$
\frac{M-M_{e q}}{M_{\theta i}-M_{e q}}=A \cdot e^{-K \cdot \theta}
$$

The Page empirical model (1949) has also been very popular, which has been used successfully to describe drying behaviour of a variety of biological materials. The model is given as

$$
\frac{M-M_{e q}}{M_{\theta i}-M_{e q}}=e^{-K \cdot \theta^{n}}
$$

Where, $M R=\frac{M-M_{e q}}{M_{\theta i}-M_{e q}}$ is the moisture ratio(MR)

A, $\mathrm{n}=$ Empirical coefficients

$\mathrm{K}=$ Drying constant, $\min ^{-1}$

$\mathrm{M}=$ Moisture content at time $\theta, \%$ (d.b.)

$\mathrm{M}_{e q}=$ Equilibrium moisture content, $\%$ (d.b.)

$\mathrm{M}_{\theta i}=$ Initial moisture content, \% (d.b.)

$\theta=$ Drying time, min

The experimental data were fitted to both the models to get the best fit based on higher value of coefficient of determination $\left(\mathrm{R}^{2}\right)$ and lower value of root mean square errors (RMSE) using MS EXCEL.

\subsection{Quality analysis of dehydrated product}

The product quality attributes which were analysed to select the best drying conditions were rehydration ratio, L-ascorbic acid content, pyruvic acid content and colour change value. The quality parameters of dried onion were determined in triplicate. Rehydration ratios (RR) of samples were determined by the methods suggested by Ranganna (1986). The rehydration ratio of the dried onion shreds was determined by immersing $2 \mathrm{~g}$ of sample with $20 \mathrm{ml}$ of distilled water $\left(30^{\circ} \mathrm{C}\right)$ in a beaker and the rehydration ratio was calculated as follows.

$$
\text { Re hydration ratio }=\frac{\text { Mass of the rehydrated sample }}{\text { Mass of the dried sample }}
$$

Ascorbic acid (vitamin C) is a major constituent of most of the fruits and vegetables which depletes significantly during the course of dehydration and storage. L-ascorbic acid was measured by a titration method based on the reduction of 2, 6- dichlorophenol indophenol dye by ascorbic acid (Ranganna, 1986). The amount of pyruvic acid generated enzymatically upon homogenization of onion in a blender is thus a good measure of the action of the alliinase on the flavour precursors and has been shown to be correlated with perceived onion pungency. The pungency in terms of pyruvic acid was determined by the method of Schwimmer and Weston (1961). Samples were homogenized and the spectrophotometer was calibrated with standard components. The Hunter 'L', 'a' and 'b' values of the dehydrated samples were measured using a Hunter Lab Colorimeter (Model: Colourflex), where 'L' measures lightness and the parameters ' $a$ ' and ' $b$ ' describe rednessgreenness and yellowness-blueness chromatically respectively. The colour difference $\Delta \mathrm{E}$ was evaluated using the Hunter-Scafield equation (Francis \& Clydesdale, 1975).

$$
\left.\Delta E=\sqrt{\left\{\left(L-L_{0}\right)^{2}+\left(b-b_{0}\right)^{2}+\left(a-a_{0}\right)^{2}\right.}\right\}
$$

Where $L_{0}, a_{0}, b_{0}$ represent the initial values of the samples.

\section{Results and discussion}

\subsection{Drying characteristics of onion slices}

The moisture loss and drying rate of raw onion slices dried in the heat pump dryer at $35,40,45$ and $50^{\circ} \mathrm{C}$ are presented in Fig. 2 and 3. Experimental results showed that drying time decreased substantially with an increase in drying air temperature as indicated by the steepness of the curves (Fig. 2). The time requirements were observed to be $840,660,480$ and 360 minutes for drying of onion slices from 675.8 to $6 \%$ (d.b.) at $35,40,45$ and $50^{\circ} \mathrm{C}$, respectively. Drying time for 
air temperature of $50^{\circ} \mathrm{C}$ was found to be the shortest owing to highest temperature and lowest relative humidity. At lower drying air temperatures, the drying time was observed to be substantially longer which was also reported by Viswanathan, Hulasare, and Jayas (2003). Drying of onion slices took place in the falling rate period (Fig. 2). The variation of drying rate with moisture content showed that there was no constant rate period in the experimental range. This indicates that diffusion is the most likely physical mechanism governing moisture movement in onion slices. The results are in agreement with Rapusas and Driscoll (1995) and Sawhney, Sarsavadia, Pangavhane, and Singh (1999) for white onion slices. It was observed that at the same moisture content, the drying rate was dependent on the air temperature. Evaporation of water was observed to be faster at the initial stage of drying. However, the effect of air temperature decreased as more water was evaporated from the onion. This would suggest that at high relative water contents, removal of water from onion undergoing drying is facilitated by temperature. Similar results were reported by Lewicki, Rajchert, and Nowark (1998). Kalbasi (2003) also reported that drying rate at high moisture content was a stronger function of air temperature. This might be due to higher vapour pressure difference as the driving force for moisture removal owing to higher moisture content of the product and higher drying air temperature.

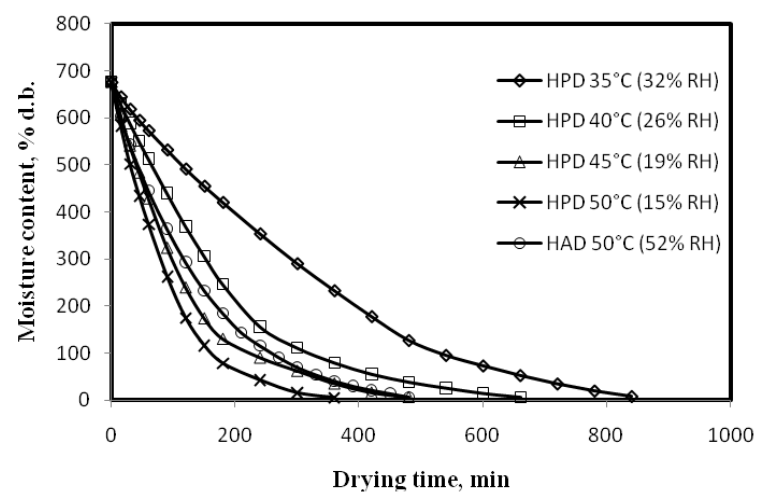

Figure 2: Variation of moisture content with drying time of onion slices dried at different drying air temperatures in the heat pump dryer

\subsection{Comparison of heat pump and hot air drying kinetics}

The drying rate was observed to be higher in the heat pump dryer as compared to the hot air dryer (Fig. 3). Drying is faster in the heat pump dryer owing to lower relative humidity of the drying air which increases the driving force for moisture removal. Adam et al. (2000) also reported reduction in drying time at lower relative humidity. The drying time was 360 minutes at $50^{\circ} \mathrm{C}$ drying air temperature in the heat pump dryer for drying of onion slices from 675.8 to $6 \%$ (d.b.), whereas it took $480 \mathrm{~min}$ in the hot air dryer. The drying time decreased by $25 \%$ in the heat pump dryer as compared to the time required by the hot air dryer at $50^{\circ} \mathrm{C}$. Drying took place under the falling rate period in both dryers.

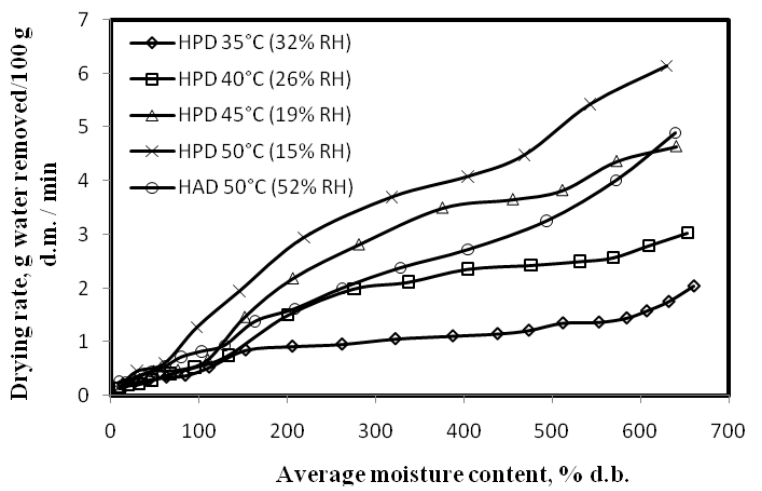

Figure 3: Variation of drying rate with moisture content of onion slices dried at different drying air temperatures in the heat pump dryer

\subsection{Development of drying equations}

The Lewis and Page equation were fitted to experimental data for onion by the direct least square procedure (Fig. 4 and 5). The model parameters, coefficient of determination and root mean square errors of the Henderson and Pabis and Page equations for onion dried at different temperatures are shown in Table 1.

It was observed that the mean value of coefficient of determination of the Page equation was higher and the root mean square error was lower than for the Henderson and Pabis equation in all the experimental runs. Hence the Page model was found to be better than the Henderson and Pabis model to describe the drying behaviour of onion slices in the heat pump dryer. Wang (2002) also reported that 
$164 \mid$ N. R. Sahoo et al.

Table 1: Drying parameters of the Henderson and Pabis and Page models for onion shreds under different drying conditions

\begin{tabular}{lcccc|ccccc}
\hline & \multicolumn{4}{c}{ Henderson and Pabis Model } & \multicolumn{4}{c}{ Page Model } \\
& $\mathrm{A}$ & \multicolumn{2}{c}{$\mathrm{K}$} & $R^{2}$ & $\mathrm{RMSE}$ & $\mathrm{K}$ & $\mathrm{n}$ & $R^{2}$ & RMSE \\
& & $\left(\mathrm{min}^{-} 1\right)$ & & & $\left(\mathrm{min}^{-} 1\right)$ & & & \\
\hline Heat pump drying & & & & & & & & & \\
$35^{\circ} \mathrm{C}$ & 1.255 & 0.0045 & 0.954 & 0.081 & 0.0018 & 1.108 & 0.986 & 0.029 \\
$40^{\circ} \mathrm{C}$ & 1.155 & 0.0069 & 0.990 & 0.041 & 0.0030 & 1.125 & 0.998 & 0.010 \\
$45^{\circ} \mathrm{C}$ & 1.076 & 0.0094 & 0.987 & 0.022 & 0.0058 & 1.079 & 0.997 & 0.013 \\
$50^{\circ} \mathrm{C}$ & 1.166 & 0.0135 & 0.988 & 0.044 & 0.0067 & 1.114 & 0.997 & 0.011 \\
Hot air drying & & & & & & & & & \\
$50^{\circ} \mathrm{C}$ & 1.215 & 0.0092 & 0.978 & 0.043 & 0.0058 & 1.057 & 0.994 & 0.014 \\
\hline
\end{tabular}

the Page model gave the best results in describing single-layer far-infrared radiation drying of onion slices.

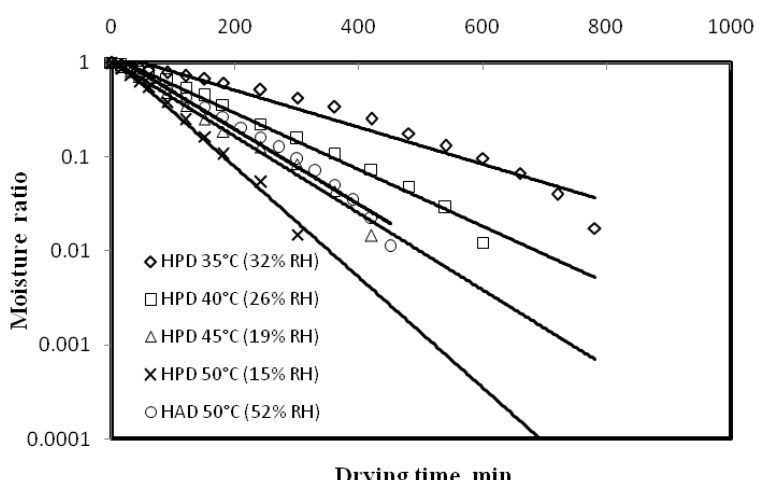

Figure 4: Fitting the Henderson and Pabis equation to experimental drying data of onion slices dried in the heat pump dryer

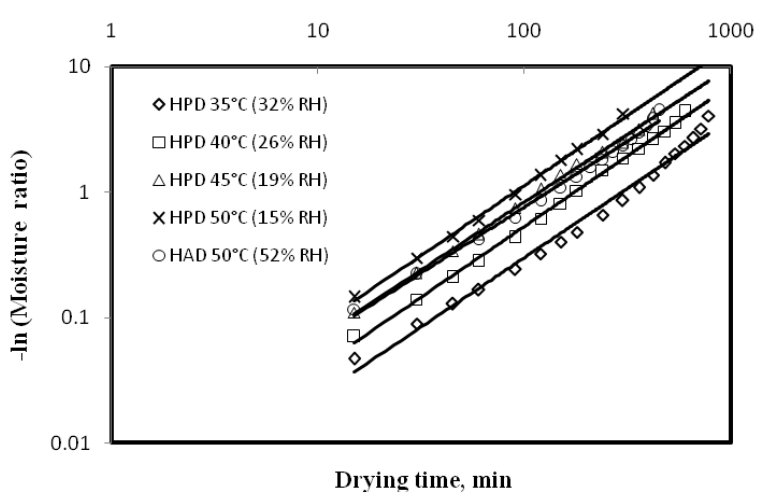

Figure 5: Drying parameters of the Henderson and Pabis and Page models for onion shreds under different drying conditions
The Page model was validated for onion slices by comparing the predicted and measured values of moisture ratios (Fig. 6). It is observed that consistency of fitting the drying data into the Page model was very good. Hence, the Page model can be used to estimate the moisture content of onions at any time during the drying process with an acceptable accuracy. The drying constant increased with the drying air temperature owing to the higher driving force for moisture removal at elevated temperature (Table 1). The drying constant in the HPD was observed to be $0.0067 \mathrm{~min}^{-1}$ which was higher than that of the $\operatorname{HAD}\left(0.0058 \mathrm{~min}^{-1}\right)$ at $50^{\circ} \mathrm{C}$ drying air temperature owing to lower relative humidity.

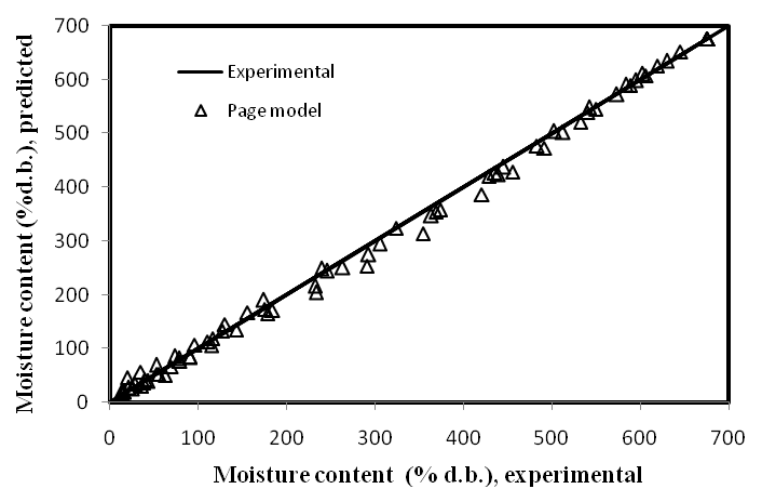

Figure 6: Comparison of experimental and predicted values of moisture content for onion slices using the Page model 
heat pump drying of Onion $\mid 165$

Table 2: Quality parameters of onion slices dried at different drying air temperatures in the heat pump dryer

\begin{tabular}{|c|c|c|c|c|c|c|}
\hline & Drying air temperature & $\mathrm{DR}$ & $\mathrm{RR}$ & $\Delta \mathrm{E}$ & $\begin{array}{l}\text { Pyruvic acid content } \\
(\mu \text { mole/g dry matter })\end{array}$ & $\begin{array}{l}\text { Ascorbic acid content } \\
\text { (mg/100 g dry matter) }\end{array}$ \\
\hline \multirow[t]{4}{*}{ Heat pump drying } & $35^{\circ} \mathrm{C}$ & 5.07 & 4.32 & 10.25 & 46.48 & 17.26 \\
\hline & $40^{\circ} \mathrm{C}$ & 5.28 & 4.71 & 9.84 & 51.43 & 19.84 \\
\hline & $45^{\circ} \mathrm{C}$ & 6.05 & 5.03 & 10.03 & 57.12 & 22.41 \\
\hline & $50^{\circ} \mathrm{C}$ & 6.79 & 5.18 & 10.21 & 56.23 & 22.30 \\
\hline Hot air drying & $50^{\circ} \mathrm{C}$ & 6.31 & 4.76 & 12.04 & 50.77 & 21.00 \\
\hline $\mathrm{CD}_{5}$ level & & NS & 0.16 & 0.21 & 1.22 & 0.26 \\
\hline
\end{tabular}

\subsection{Quality of heat pump dried onion slices}

The quality parameters of onion slices dried under different conditions in the heat pump and hot air dryers are given in Table 2. It was found that the dehydration and rehydration ratios increased with increase in drying air temperature. This might be due to the lower equilibrium moisture content of samples dried at higher temperature and more water uptake during rehydration. Product colour is one of the important quality parameters that needs to be maintained during onion drying. The colour change was found to be greater at the lower temperature of $35^{\circ} \mathrm{C}$, probably due to the prolonged drying time of $840 \mathrm{~min}$. However, there was not much variation in colour change of samples dried at different temperatures in the heat pump dryer. Samples dried at $50^{\circ} \mathrm{C}$ in the heat pump dryer were observed to maintain the colour better as compared to hot air dried samples, which might be due to less drying time in the HPD.

The vitamin $\mathrm{C}$ content of onion is considered important amongst the nutritive quality criteria of the product. In the fresh onion, the L-ascorbic acid amounted to 27.2 $\mathrm{mg} / 100 \mathrm{~g}$ dry matter and pyruvic acid content was 66.3 $\mu$ mole/g dry matter. The drying air temperature of $35^{\circ} \mathrm{C}$ adversely influenced the quality of dried onion. Loss of pyruvic acid and ascorbic acid content were observed to be more in the heat pump dried samples at $35^{\circ} \mathrm{C}$ due to longer drying time. Sarsavadia (2007) also reported that a longer drying period, during which the product is exposed to atmospheric oxygen, had an adverse effect on some quality aspects like reduction in ascorbic acid. Adam et al. (2000) found that a longer drying time and hence longer exposure period to the drying air resulted in a decrease of the pyruvate and ascorbic acid contents. The retention of pyruvic and ascorbic acid was higher in samples dried at 45 and $50^{\circ} \mathrm{C}$. Since there is not much variation in the values of ascorbic acid and pyruvic acid content of samples dried at 45 and $50^{\circ} \mathrm{C}$ in the $\mathrm{HPD}$ and samples dried at $50^{\circ} \mathrm{C}$ takes less time, it is recommended to dry samples at $50^{\circ} \mathrm{C}$ in heat pump dryer.

The dehydration and rehydration ratios of the heat pump dried samples at $50^{\circ} \mathrm{C}$ were found to be higher than that of hot air dried samples. This might be due to lower equilibrium moisture content of samples dried in the heat pump dryer, owing to lower relative humidity. During drying at $50^{\circ} \mathrm{C}$, the colour change value of dried product was observed to be less in the heat pump dryer (15\% R.H.) as compared to the hot air dryer (52 $\%$ R.H.). This could be attributed to the fact that, at higher humidity, the drying time was considerably increased and the rate of browning reaction could be also increased with increasing relative humidity of the drying air. Adam et al. (2000) suggested avoiding drying at relative humidity above $40 \%$ in order to prevent colour change.

The retention of pyruvic and ascorbic acids was higher in heat pump dried samples as compared to hot air dried samples at $50^{\circ} \mathrm{C}$. This might be due to less drying time in the heat pump dryer owing to lower relative humidity of drying air. In view of the above findings, heat pump drying was found to be better than hot air drying at the same drying air temperature of $50^{\circ} \mathrm{C}$. Furthermore, heat pump drying at $50^{\circ} \mathrm{C}$ was found to be the best drying temperature under investigation.

\section{Conclusions}

The drying time was 360 minutes at $50^{\circ} \mathrm{C}$ drying air temperature in the heat pump dryer for drying of onion slices from 675.8 to $6 \%$ (d.b.), whereas it took $480 \mathrm{~min}$ in the hot air dryer. The Page equation, resulting in a 
higher coefficient of determination and lower root mean square error, better described the thin-layer drying of onion slices than the Henderson and Pabis equation. The quality parameters such as rehydration ratio, retention of colour, ascorbic acid content and pyruvic acid content of onion slices obtained from the heat pump dryer at $50^{\circ} \mathrm{C}$ were best among all the samples. Hence, a drying air temperature of $50^{\circ} \mathrm{C}$ was recommended for drying of onion slices in the heat pump dryer with less drying time and maintaining the quality parameters as well.

\section{References}

Adam, E, Mühlbauer, W, Esper, A, Wolf, W, \& Spiess, W. (2000). Quality changes of onion (Allium Cepa L.) as affected by the drying process. Nahrungfood, 44(1), 32-37. doi:\{10 . 1002 / (SICI ) 1521 3803(20000101)44:1〈32::AID-FOOD32〉3.3.CO;26\}

Adapa, P., Sokhansanj, S, \& Schoenau, G. (2002). Performance study of a re-circulating cabinet dryer using a household dehumidifier. Drying Technology, 20(8), 1673-1689. doi:\{10.1081 / DRT $120015407\}$

Chua, K., Chou, S., Ho, J., \& Hawlader, M. (2002). Heat pump drying: Recent developments and future trends. Drying Technology, 20(8), 1579-1610. doi:\{10.1081/DRT-120014053\}

Francis, F., \& Clydesdale, F. (1975). Food calorimetry: theory and applications. Westport, Connecticut: The AVI publishing Company Inc.

Henderson, S., \& Pabis, S. (1961). Grain drying theory i. temperature effect on drying coefficient. Journal of Agricultural Engineering Research, 6, 169-174.

Hernandez, J., Pavon, G, \& Garcia, M. (2000). Analytical solution of mass transfer equation considering shrinkage for modeling food-drying kinetics. Journal Of Food Engineering, 45(1), 1-10. doi:\{10. 1016/S0260-8774(00)00033-9\}

Holdsworth, S. (1986). Advances in the dehydration of fruits and vegetables. in d. mccarthy (ed). concentration and drying of foods. London: Elsevier Applied Science Publ. 293-303.

Kalbasi, M. (2003). Heat and moisture transfer model for onion drying. Drying Technology, 21 (8), 15751584. doi: $\{10.1081 /$ DRT-120024492\}

Kaymak-Ertekin, F, \& Gedik, A. (2005). Kinetic modelling of quality deterioration in onions during drying and storage. Journal Of Food Engineering, 68 (4), 443-453. doi:\{10.1016/j.jfoodeng.2004.06. $022\}$

Lewicki, W., PP andLazuka, Rajchert, D., \& Nowark, D. (1998). Effect of mode of drying on storage stability of coloured dried onion. Polish Journal of Food and Nutrition Sciences, 48(4), 701-706.

Madamba, P., Driscoll, R., \& Buckle, K. (1996). The thin-layer drying characteristics of garlic slices. Journal Of Food Engineering, 29(1), 7597. doi: $\{10.1016 / 0260-8774(95) 00062-3\}$

Malchev, E, Ioncheva, N, Tanchev, S, \& Kalpakchieva, K. (1982). Quantitative Changes in Carotenoids During the Storage of Dried Red Pepper and Red Pepper Powder. Nahrung-food, 26 (5), 415-420.

Pal, U. S., \& Khan, M. K. (2007). Heat pump drying of food materials: A critical review. Journal Of Food Science And Technology-mysore, 44 (2), 119-124.

Pal, U. S., \& Khan, M. K. (2008). Calculation steps for the design of different components of heat pump dryers under constant drying rate condition. Drying Technology, 26(7), 864-872. doi:\{10.1080/ $07373930802142226\}$

Pezzutti, A, \& Crapiste, G. (1997). Color changes during dehydration of onion (Allium cepa L) and garlic (Allium sativum L). In Burba, JL and Galmarini, CR (Ed.), First international symposium on edible alliaceae (433, 455-462). Acta Horticulturae. 1st International Symposium on Edible Alliaceae, Mendoza, Argentina, March 14-18, 1994.

Ranganna, S. (1986). Handbook of analysis and quality control for fruit and vegetable products. 2nd Ed. New Delhi: Tata Mc Graw Hill Publishing Co.

Rapusas, R., \& Driscoll, R. (1995). Kinetics of Nonenzymatic Browning in Onion Slices During Isothermal Heating. Journal Of Food Engineering, 24(3), 417-429. doi:\{10.1016/0260-8774(95)90054-F\}

Sarsavadia, P. N. (2007). Development of a solarassisted dryer and evaluation of energy requirement for the drying of onion. Renewable Energy, 32(15), 2529-2547. doi:\{10.1016/j.renene.2006. $12.019\}$

Sawhney, R., Sarsavadia, P., Pangavhane, D., \& Singh, S. (1999). Determination of drying constants and their dependence on drying air parameters for thin layer onion drying. Drying Technology, 17(1-2), 299-315. doi: $\{10.1080 / 07373939908917531\}$

Schwimmer, S, \& Weston, W. (1961). Onion Flavor and Odor - Enzymatic Development of Pyruvic Acid in Onion as a Measure of Pungency. Journal Of 
heat pump drying of Onion $\mid 167$

Agricultural And Food Chemistry, 9(4), 301-304. doi: $\{10.1021 /$ jf60116a018\}

Sharma, G., Verma, R., \& Pathare, P. (2005). Mathematical modeling of infrared radiation thin layer drying of onion slices. Journal Of Food Engineering, $71(3), 282-286$. doi:\{10.1016/j . jfoodeng . 2005.02.010\}

Viswanathan, R, Hulasare, R, \& Jayas, D. (2003). Drying characteristics of shredded onion (Allium cepa). Journal Of Food Science And Technologymysore, 40(5), 521-524.

Wang, J. (2002). A single-layer model for far-infrared radiation drying of onion slices. Drying Technology, 20(10), 1941-1953. doi:\{10.1081/DRT$120015577\}$

Williams, S. E. (1984). Official methods of analysis of the association of official analytical chemists. 14th Ed. Washington. D.C: Association of Official Analytical Chemists. 